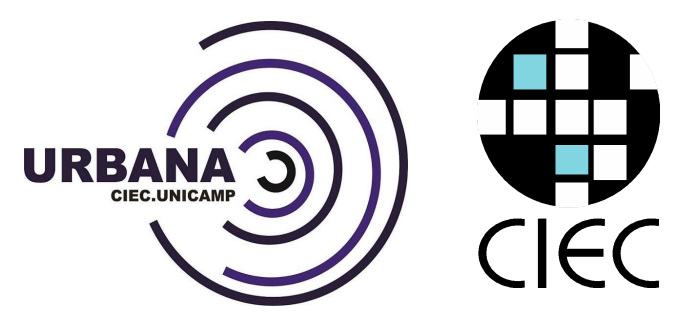

URBANA: Revista Eletrônica do Centro Interdisciplinar de Estudos sobre a Cidade

Cristina Martins Tavelin [entrevista Felipe Marcondes da Costa]

cristina.tavelin@gmail.com | Universidade Federal do Rio de Janeiro

\title{
Em obras / Em ruínas
}

In progress/In ruins

En obras/ En ruínas

O projeto Escritas do efêmero toma as ruas para construir e destruir parâmetros sobre o que é fazer literatura

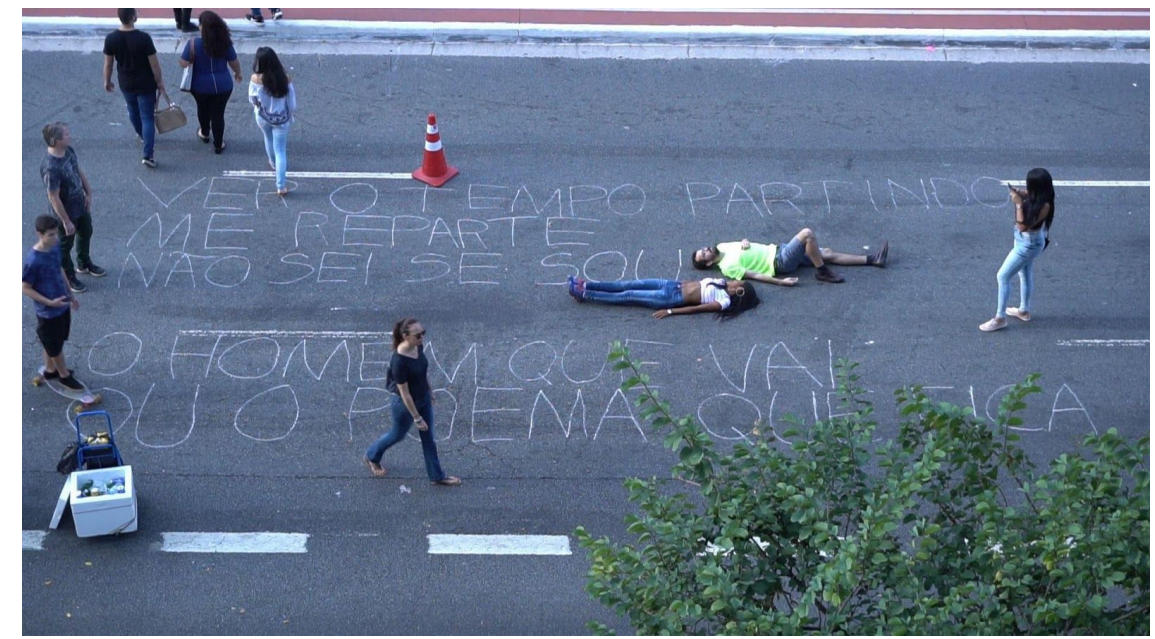

Figura 1: Escritas do efêmero \#1: poema contínuo, São Paulo, 2018.

Fonte: Acervo do autor. 
Entrevistadora: $O$ senso comum tende a conceber a literatura a partir de uma figura ensimesmada, solitária. Sua ação afasta a escrita das quatro paredes - muito identificada com determinada classe social que pode usufruir do exercício do ócio - e a faz ocupar outro lugar, muito mais palpável. De onde veio o ímpeto de ir pra rua?

Felipe Marcondes da Costa: A vontade fundamental era de ser lido. Essa tentativa já vinha do rezar é juntar palavras com força, na opção de publicar com a Dulcineia [Catadora, coletivo paulistano que publica livros cartoneros num trabalho conjunto com uma cooperativa de catadoras de papelão], de fazer um livro acessível e que chegasse a pessoas que não necessariamente compunham um público leitor. Eu pensava que quem mais precisava ler o que eu escrevia era justamente quem não tinha o hábito ler. Pensei em fazer oficinas de leitura a partir dos poemas desse livro como um modo de formação de público. Ainda assim, percebi que, mesmo cartonero, o formato livro por si só não chegava a essas pessoas. Então fui levar as duas únicas coisas que tenho, minha escrita e meu corpo, pro espaço público. Fazer dos dois uma coisa só e colocar à disposição de quem tropeçasse neles. Então dá pra dizer que o escritas na rua veio dessa necessidade de encontro com o público mesmo, de não só pregar pra convertido, mas de tocar um público que de antemão nem se sabia público. 


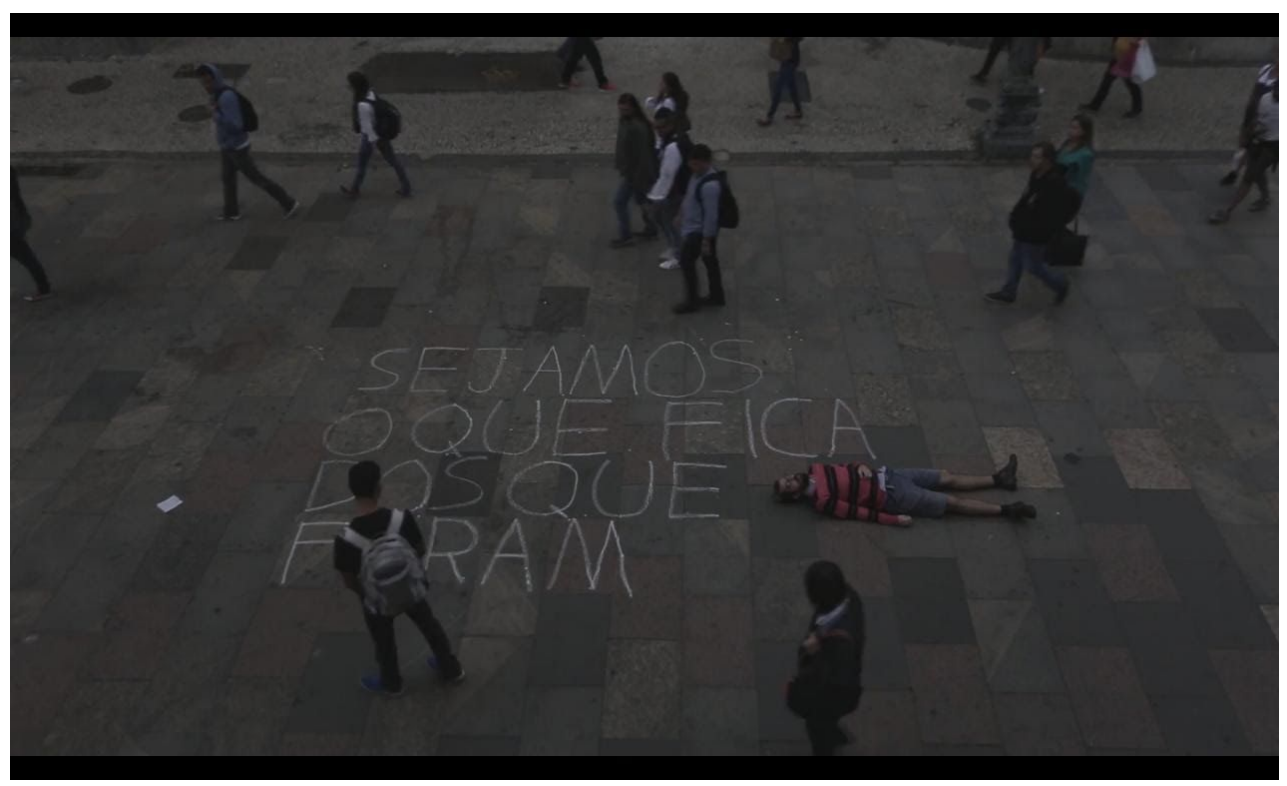

Figura 2: Escritas do efêmero \#4: podem até decidir o modo como morremos mas isso não irá decidir o modo como vivemos, Rio de Janeiro, 2018.

Fonte: Acervo do autor.

E: Tanto na opção de publicar o rezar é juntar palavras com força pela Dulcineia Catadora - que não trabalha com ISBN e, por isso, oficialmente não conta como publicação - quanto no modo de organização e circulação do Escritas do efêmero, um certo "espírito amador" prevalece como projeto estético, importante no modo de recepção desses trabalhos. Fale mais da relação do surgimento do Escritas com a publicação do rezar.

FMC: Eu já não pensava em publicar um livro físico, porque pra mim seria contraditório, com meus objetivos naquele momento, publicar por uma editora convencional, já que só o fato de publicar um livro assim já reafirmaria um sistema literário que eu justamente queria criticar. Então a oportunidade de publicar com a Dulcineia Catadora, com as capas de papelão pintadas a mão, impressão em papel reciclado, tiragem pequena, toda distribuição feita por nós mesmos, foi algo que me animou a reunir poemas que seriam potencializados por esse formato. Engajar meus amigos, que já me leriam, e as catadoras, que era também esse público que eu buscava dialogar, na produção de livros que não visavam o lucro, já que todo 
o dinheiro levantado é revertido pra cooperativa das catadoras se sustentar e poder publicar outros autores, era o tipo de ciclo virtuoso que eu buscava sustentar com meu trabalho. É por outros modos de vida como esse que o rezar clamava, e poder fortalecer uma iniciativa assim é ótimo! Eu não podia acreditar em publicar um livro e cobrar 40 reais dos meus amigos - já que só eles que acabariam comprando mesmo. Além de que quase nada desse dinheiro chegaria a mim. Então quer dizer, já não me atraía esse circuito profissional, sou muito mais amador, como quem ama mesmo. Isso foi em 2017. É também desse espírito amador que surge o escritas já no primeiro semestre de 2018, com dois caras, um levando seu corpo e o outro levando sua câmera, se atirando pra rua num projeto que é também de formação de público.

E: Pensando no ímpeto de colocar a escrita na rua e também numa questão mais prática, de contar com o trabalho de catadoras pra uma publicação, você diria que a dimensão política é um aspecto fundamental nesses trabalhos?

FMC: A dimensão política, sim. No Brasil em que surge o escritas, isto é, de 2018, não há como não levar em conta a realidade social do país. $E$ isso é muito interessante, porque pelo momento em que tava inserido, e pela minha intenção de transcender os espaços institucionalmente destinados à arte, muitos batiam o olho e falavam "vixi, olha o protesto" até antes de ler o que tava escrito. Aí quando lia, já ficava pensando que "protesto" seria aquele. Era também um estranhamento de uma estética do protesto, muito em voga. Então a dessacralização de levar o trabalho pra rua faz com que muitas vezes ele nem seja reconhecido como arte, o que é ótimo, porque tirando essa pecha as pessoas se sentem muito mais próximas e inseridas, longe daquele "ambiente artístico" muitas vezes chato e elitista em que se sentem excluídas. É muito bom poder explorar esse lugar do estranhamento. Logo na primeira ação, duas meninas se aproximaram de mim e perguntaram: "isso é uma intervenção artística ou você é só...?". Essas reticências queriam dizer "ou você é 
só um maluco?". Eu respondi: "as duas coisas". Quer dizer, se você faz uma coisa e diz que é arte você é visto como artista, mas, se fizer a mesma coisa e não disser que é arte, aí te veem só como um maluco mesmo. E o grande lance é justamente borrar essas fronteiras, captar o olhar entre desconfiado e curioso do transeunte que por acaso tá passando ali naquela hora. Ao não identificar rapidamente do que se trata aquela manifestação, ele pode se sentir convidado a participar ou se sentir repelido. Isso tudo só mostra a dimensão política que já está dada ao se dispor a ir pra rua. Nesse aspecto de se expor e estar aberto ao diálogo, acho que estar deitado ajuda muito. Há posição pra estar mais aberto do que deitado? A abertura formal que há também no trabalho, de eu não ter formação em pintura, escultura, nada, estar fazendo algo "que qualquer um poderia fazer", com materiais de baixo custo, em locais acessíveis, acho que essa simplicidade toda também chama e deixa a pessoa à vontade pra chegar junto, interagir. Acho que isso de a gente fazer do jeito que dá, de não ficar esperando o mundo oferecer as condições ideias pra agir, aproxima as pessoas. Porque se depender de condições a gente nem tinha começado... O movimento gera movimento, as pessoas entram no fluxo. Claro que não temos as condições ideias, mas o mundo que vivemos também não é o ideal. $E$ a simplicidade aproxima, a afetação afasta. É nesse sentido que me parece que ser tosco pode se tornar uma potência. Acho que cada vez mais a arte deverá se parecer menos com o que se entende por arte. Então sim, sem a dimensão política talvez meus trabalhos nem pudessem ser considerados arte, até porque a essa altura nem há arte sem política. Então nem sei se é um mérito meu, me parece que a isenção política é um privilégio do qual pessoas como eu não gozam. 


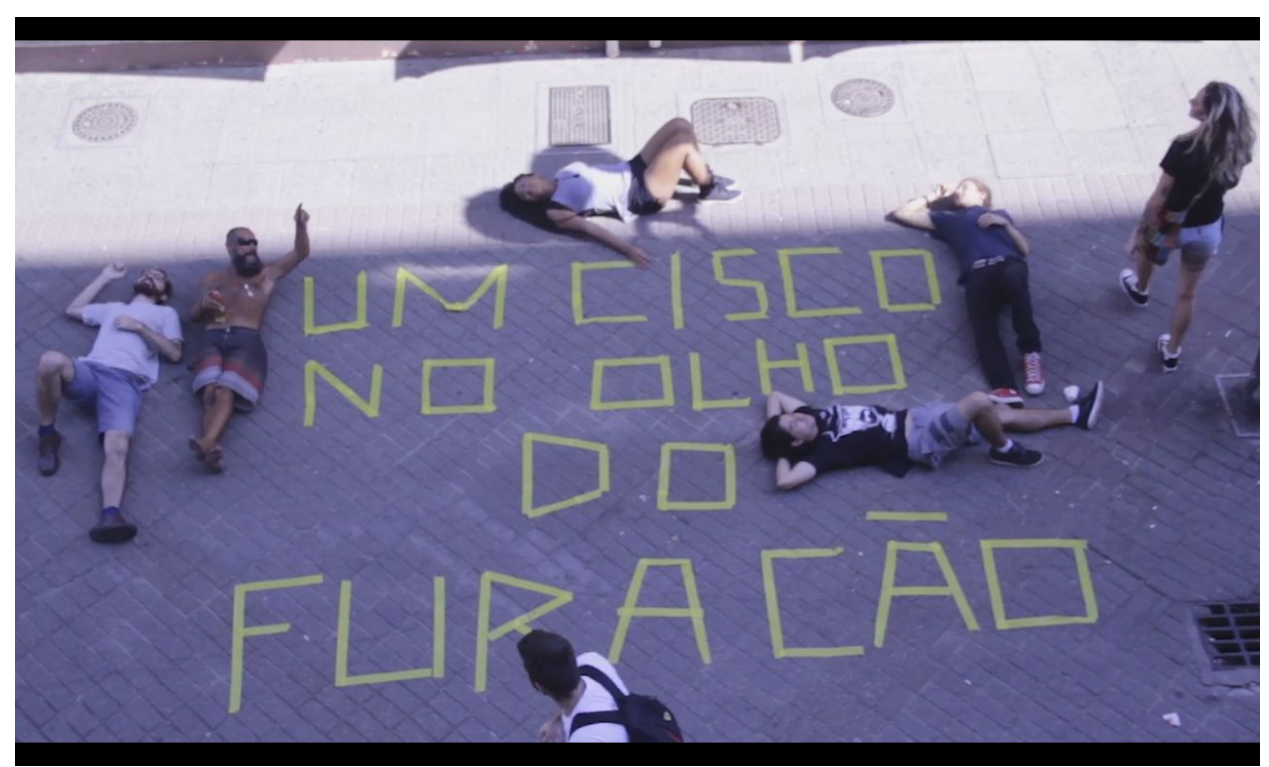

Figura 3: Escritas do efêmero \#8: aterrar, Florianópolis, 2019.

Fonte: Acervo do autor.

E: Ainda faz sentido pensar sobre a questão "o que é arte"? Tudo pode ser arte?

FMC: Costumo trabalhar com a célebre definição do Godard: "Cultura é regra, arte é exceção". Mais que uma mera frase de efeito, acho que há muito aí, pensando como cultura aquilo que a gente bate o olho e logo identifica dentro de nosso repertório e arte como aquilo que desestabiliza, que causa estranhamento. Talvez até soe tautológico, mas eu complementaria dizendo que o que mais me interessa na arte é aquilo que não é arte, e o que mais me interessa no que não é arte é justamente aquilo que pode ser arte. Acho que o meu "o que é, o que é" sobre arte ficaria por aí. 


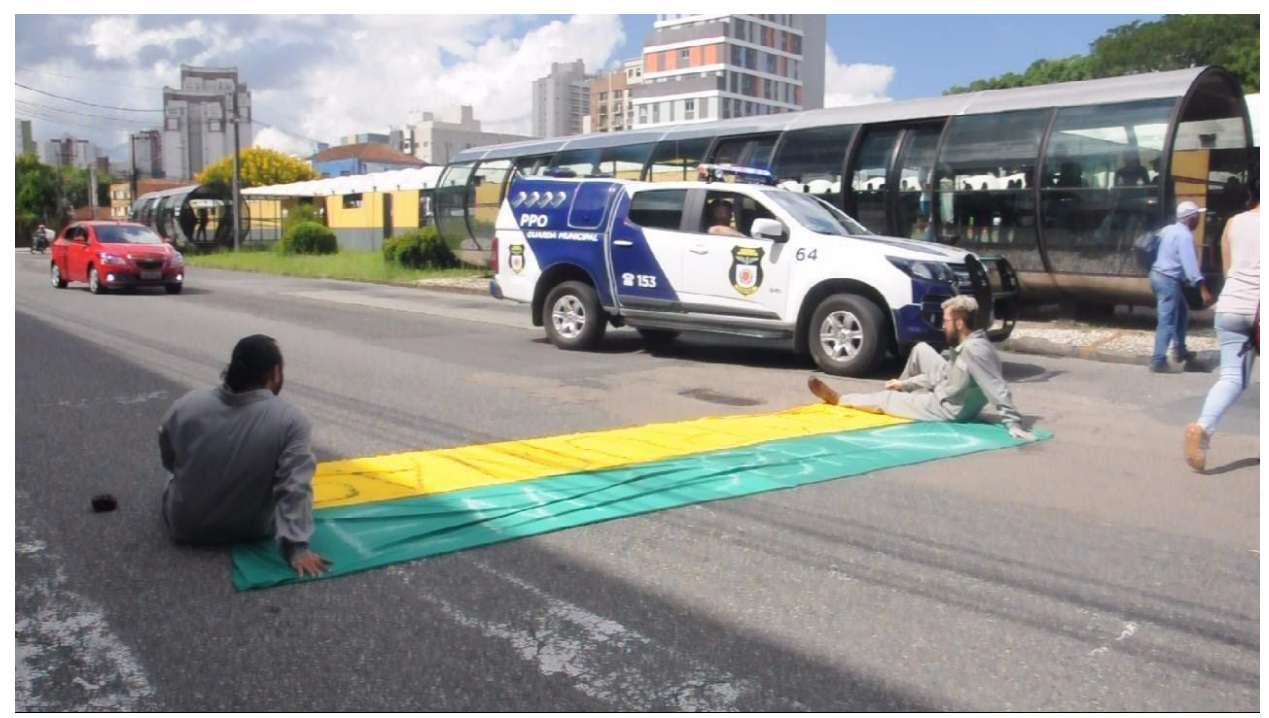

Figura 4: Escritas do efêmero \#6: construção, Curitiba, 2019.

Fonte: Acervo do autor.

E: De onde veio o nome Escritas do efêmero?

FMC: Quando pensei em ir pra rua, a ideia fundamental já era a de trabalhar uma expressão que não se confundisse com algo rapidamente identificável, como o pixo. Não só porque isso seria enquadrado como uma estética já reconhecida, mas também porque não tínhamos a pretensão de ocupar esse espaço que diz respeito muito mais a outras pessoas. Enfim, naquele momento eu estava já aprofundando os estudos em performance e tava louco pensando em possibilidades de performar a escrita: estava certo que queria engajar o corpo, que queria atuar no espaço público pra gerar interação e interrupção no cotidiano e que isso consistiria numa ação efêmera, mas com registro em vídeo. Foi aí que dei a ideia ao Marcelo [Vinci, também do coletivo Alterquia] de irmos à [Avenida] Paulista num domingo, em que ela é fechada pros carros, e fazer essa experiência. E era realmente uma experiência, não tinha maiores pretensões, tanto que a gente foi sem grandes expectativas e veríamos depois se viraria alguma coisa. Se não virasse nada, ao menos teria valido pela experiência de atuação na rua. E desde aquela vez continua sendo uma experiência sem maiores pretensões, 
apesar das experiências tão surpreendentes que essas ações já nos proporcionaram.

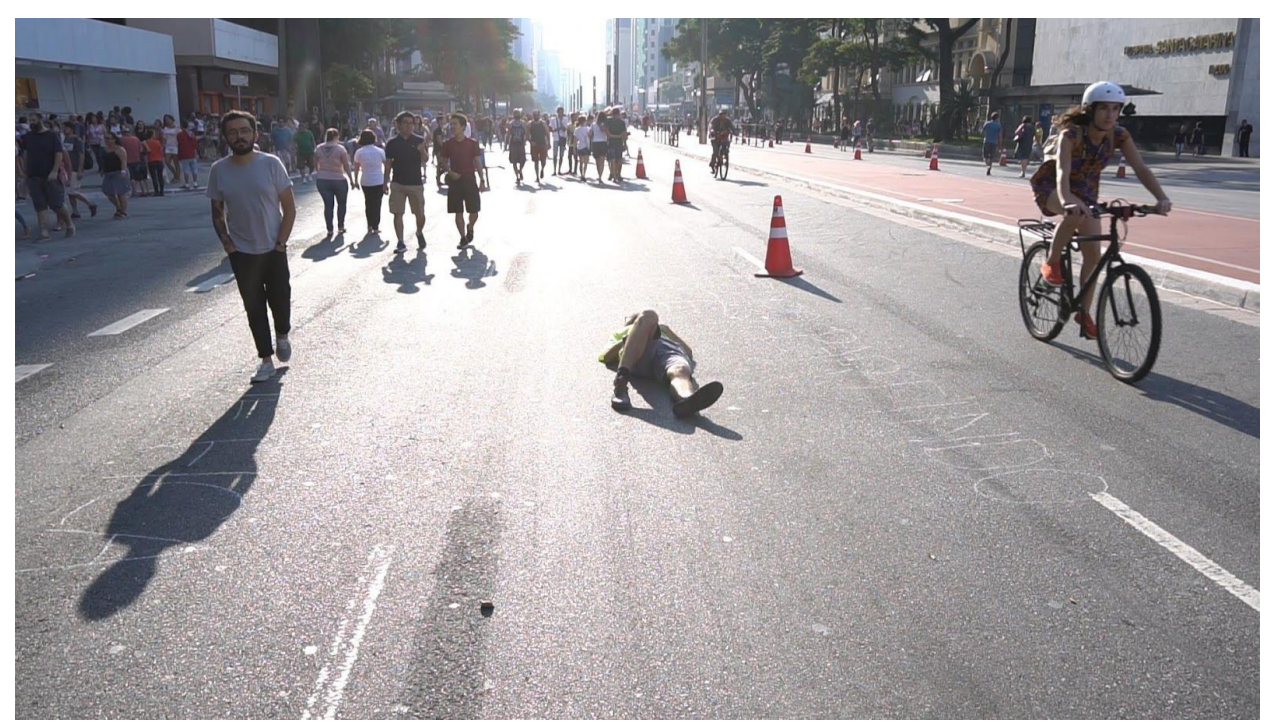

Figura 5: Escritas do efêmero \#1: poema contínuo, São Paulo, 2018.

Fonte: Acervo do autor.

E: E quando você se deu conta que essas experiências estavam forjando uma linguagem?

FMC: Assim que comecei a escrever pela primeira vez com giz no asfalto algo começou a se movimentar: uma criança veio brincar com o desenho das letras e as pessoas começaram a olhar curiosas. Claro que ali havia toda uma abertura, porque era domingo e todo mundo tava passeando na Paulista aberta, então dá pra dizer que havia uma pré-disposição. Mesmo assim, a interação que imaginei estava acontecendo muito melhor do que o esperado. Então, quando deitei a coisa realmente aconteceu. E deitado ali eu não tinha certeza, porque minha cabeça ficava pra cima e eu só via o céu, praticamente não tinha visão periférica, mas percebia que algum impacto tava de fato ocorrendo, porque nunca ouvi tanta gente me lendo em voz alta. É lindo ver um texto acontecendo assim! Quando as pessoas começaram a me abordar e chegaram a deitar comigo ali no chão então, aí foi incrível. Fiquei uma hora e meia deitado, mas dizer que fiquei uma hora e meia não dá a dimensão do tempo que passei ali. 
Quando encontrei o Marcelo, ele tava muito empolgado com tudo que havia registrado. E eu tava em jejum - prefiro atuar em jejum, porque me ajuda na concentração, em estar no aqui-e-agora -, então tive que segurar a ansiedade porque já era fim de tarde e o estômago tava cobrando seu tributo. Então só fui ver alguns takes depois de comer, ainda assim muito rapidamente. Só deu pra ver que o enquadramento tinha ficado mais muito bonito. Que ia ficar esteticamente bonito enquanto imagem eu já imaginava, confesso, mas só ser bonito também não quer dizer nada. Tinha que ter algo mais. Quando caiu a noite, captamos ainda umas imagens. Apenas o rastro da escrita, quase ilegível, iluminado pelos faróis dos carros que já tinham voltado a circular pela pista.

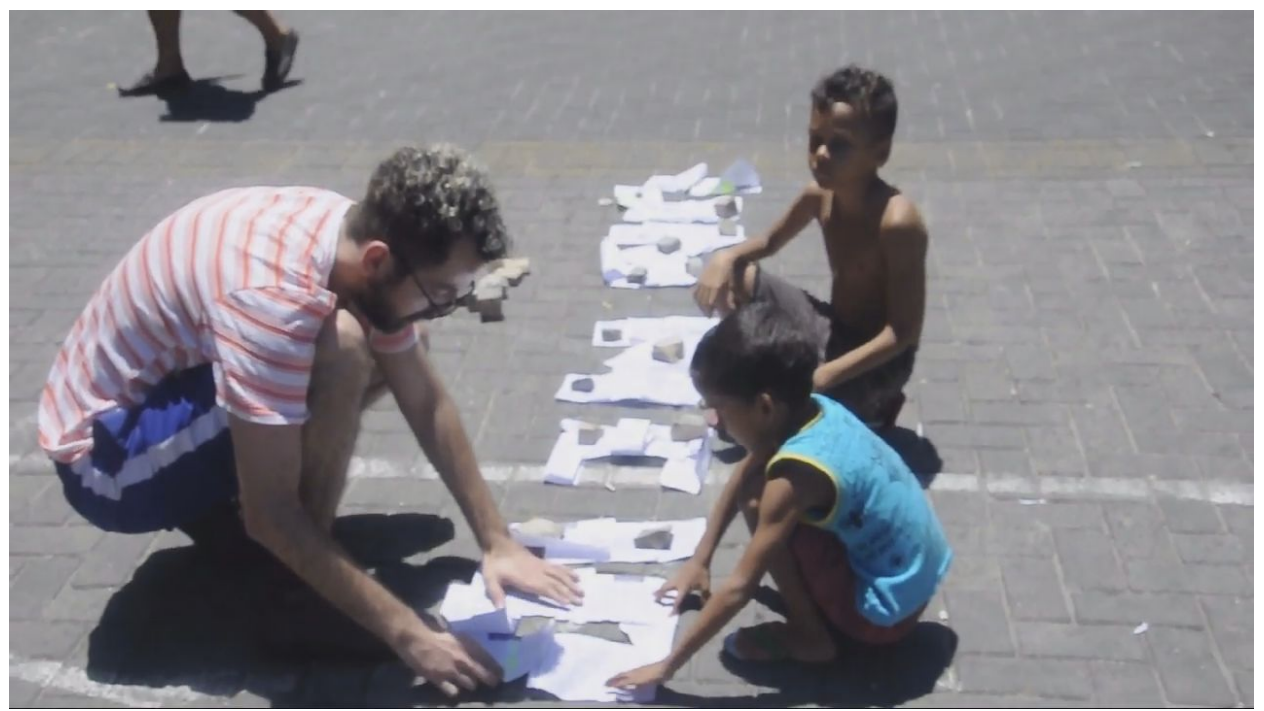

Figura 6: Escritas do efêmero \#5: volta, Recife, 2018.

Fonte: Acervo do autor.

E: Praticamente desde o início da arte da performance há um debate sobre a questão da documentação: se as fotos e vídeos são indissociáveis da experiência realizada ao vivo com o público ou se configuram algo à parte. Como é sua relação com a produção imagética e qual a importância do vídeo nesse processo?

FMC: O vídeo é o salto dessas ações, que duram apenas aquelas horas e só podem ser vistas pelos presentes, pra uns 
minutos que vão perdurar por muito mais tempo e podem chegar em muito mais gente. O vídeo é a possibilidade de suspensão do efêmero. Veja, a maioria dos trabalhos de performance que a gente tem contato, os trabalhos históricos, são todos mediados por documentação em fotografias ou vídeos. Vou te dizer que me emocionei quando vi o trabalho de edição do Marcelo, não só por ser muito bem feito, mas porque é como se eu tivesse descobrindo alguma coisa, talvez me descobrindo. E isso é muito bom, porque acredito que performance precisa transformar algo: seja você, seja o outro. Pelo menos um dos dois tem que transformar; se for os dois, melhor. A gente conversou antes que o vídeo não teria que mimetizar a experiência de quem estivesse ali na hora, porque isso seria ingênuo, não funcionaria, mas deveria instaurar outra experiência com o espectador, que não presenciou a ação mas poderia estabelecer outro tipo de relação a partir do contato com o vídeo. Quando escrevo e deito ali eu não estou preocupado em performar pro vídeo, porque a ideia era também performar no vídeo. E aí é um trabalho posterior, de montagem. Além de tudo, a tentativa era de chegar em pessoas que dificilmente abririam um livro, e teríamos duas frentes pra isso: a rua e a internet, onde o vídeo circula. Então, sobre forjar uma linguagem, só fiquei realmente confiante quando vi o vídeo e ele teve uma boa recepção. Era mais do que só um enquadramento bonito, realmente dizia algo às pessoas. 


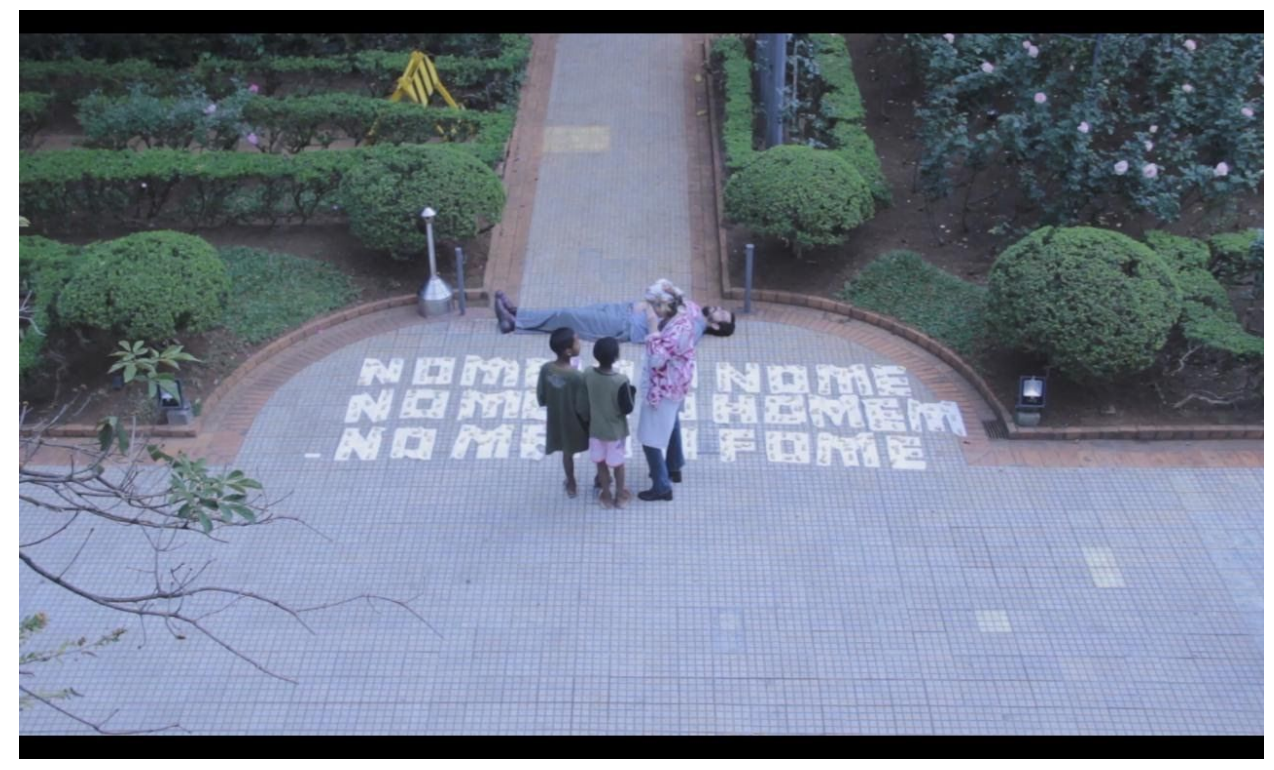

Figura 7: Escritas do efêmero \#3: no meio a fome, São Paulo, 2018.

Fonte: Acervo do autor.

E: A internet é a nova rua?

FMC: Creio que essa afirmação nunca vai se realizar plenamente, porque à internet falta corpo. A presença é uma coisa que põe a coisa toda em outro lugar, por conta disso o verdadeiro encontro só pode estar na rua, com nossos corpos. Por exemplo, quis fazer uma experiência de escrever e deitar, fazer meu corpo habitar essa escrita, em relação de interdependência. Isso dá um peso à escrita, as pessoas passam e dão atenção àquilo. E também dava um peso ao meu próprio corpo. Por isso, fazia parte da experiência em determinado momento levantar e deixar a escrita por conta, à deriva. E a gente percebe ainda mais o quanto o corpo é capaz de dar estabilidade ao texto, numa composição com as letras e com o sentido, quando ele sai dali. Com o corpo, dificilmente alguém passava por cima. Abandonadas, as letras foram sendo pisoteadas e se apagando. Acho que essa metáfora sobre a presença do corpo também pode se aplicar à internet que, se for uma rua, é uma rua sem esquinas, em que os encontros são de outra ordem. 


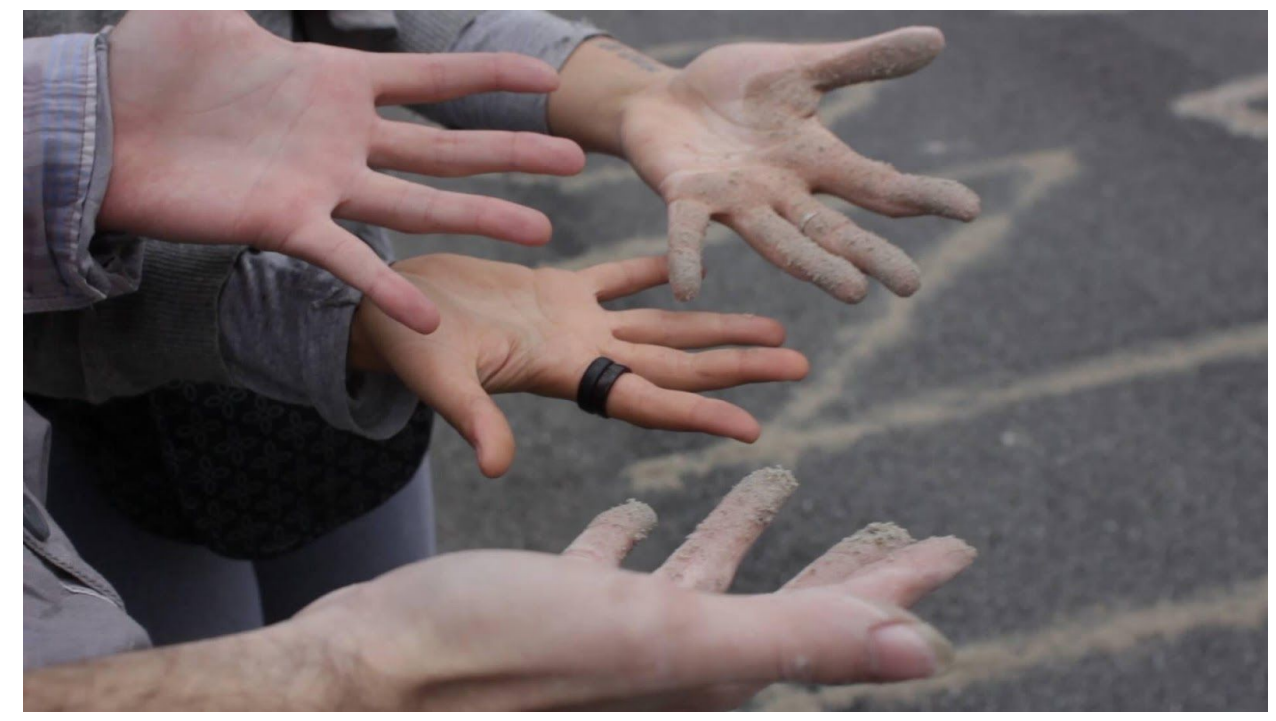

Figura 8: Escritas do efêmero \#2: desterrado, São Paulo, 2018.

Fonte: Acervo do autor.

E: A cidade, como estamos discutindo, é espaço fundamental para produção e recepção desse trabalho. Como se dá a escolha dos locais para o desenvolvimento de cada ação?

FMC: Ah, a cidade é cheia de esquinas e encontros. A implicação da cidade determina o trabalho no antes e no durante. Antes quando pensamos como intervir naquele espaço e as implicações que estão postas de antemão, no durante interfere o modo como as pessoas vão interagir. Grande parte da força do trabalho reside nesse inesperado que é o do encontro, nas surpresas que a presença do outro é capaz de proporcionar. Por exemplo, a participação - mais que participação, a coautoria mesmo - dos meninos da ocupação Marielle Franco em Recife torna o trabalho outra coisa. E não foi nada planejado. Diria mesmo que o mais bonito no trabalho é isso que nos escapa, quando o trabalho foge ao nosso controle a partir da intervenção dos outros corpos que ocupam aquele espaço. E isso é fundamental, que vivam aquele espaço. Tanto que nosso trabalho só se completa com o outro, mesmo antes de irmos pra rua, porque a gente quando vai pra outra cidade se articula com interessados dali em participar da nossa ação. E não é uma coisa hierarquizada. A pessoa vem perguntando "o que posso fazer?" e eu 
digo "tudo". Então a partir daí a gente pensa em possíveis locais, materiais, só o texto que acaba chegando uma coisa mais pronta mesmo, porque demandaria um tempo de debate com os participantes que eu ainda não tive, já que é sempre tudo corrido. Em Recife mesmo, foram dois dias na cidade pra cinco dias no ônibus. $E$ tem também as questões práticas, de fluxo de pessoas, luz, ponto de filmagem. Se a gente trabalhasse com um drone não teria isso, mas é tudo na mão mesmo, na marra, então tem que ter um ponto mais alto pra captarmos as imagens de cima, geralmente um prédio. Tudo isso só pode vir das pessoas que vivem aquele lugar, não de um forasteiro pretensioso que vem de longe com um trabalho pronto querendo falar pelos outros de modo impositivo. Eu realmente acredito que a matéria fundamental de uma cidade são as pessoas. Pelo menos, é o que mais me interessa, é o que me faz voltar ou não pra uma cidade.

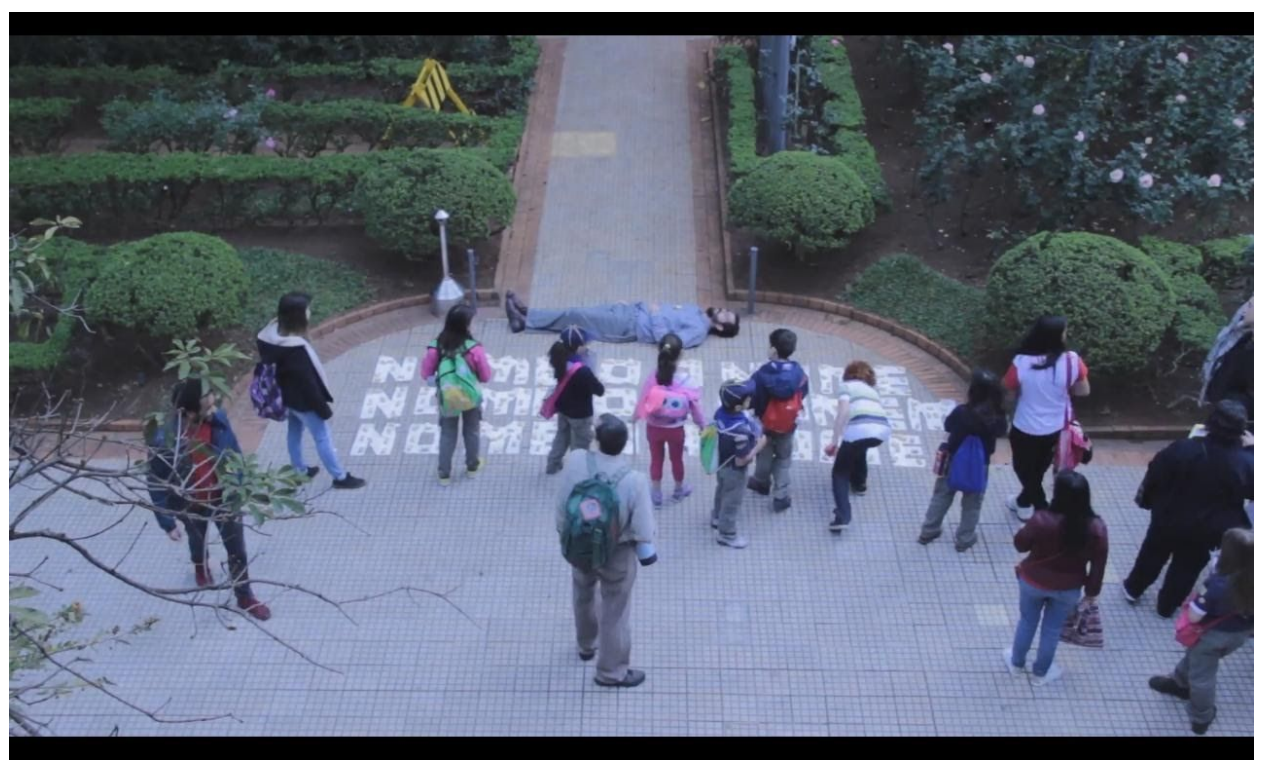

Figura 9: Escritas do efêmero \#3: no meio a fome, São Paulo, 2018.

Fonte: Acervo do autor.

E: São muitos parâmetros em jogo: texto, material de escrita, espaço, enquadramento, contexto... Como dar conta disso tudo? 
FMC: Assumir que não vai dar conta e nem ter tamanha pretensão. Você cria as condições pra que as coisas se manifestem e se coloca à disposição delas. A gente lida com artes visuais, literatura, audiovisual, performance... Também por conta desse hibridismo, acho que conseguimos não nos repetir. A partir do momento que acharmos que já temos controle pleno dos parâmetros, que não há mais nada por descobrir, aí a força já vai ter se esgotado e o melhor será explorar outros terrenos ainda férteis. É pouco provável que eu consiga desautomatizar o cotidiano se eu próprio estiver operando no automático. Por enquanto, cada ação tem sido única.

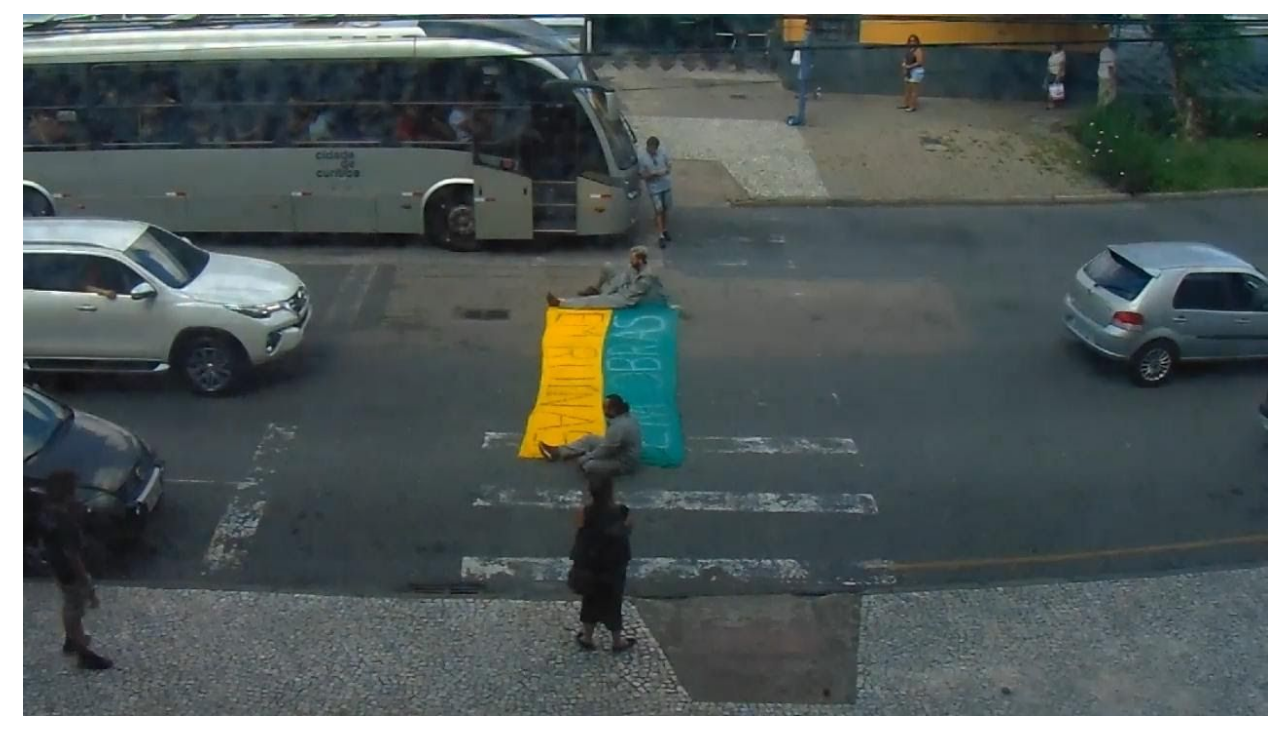

Figura 10: Escritas do efêmero \#6: construção, Curitiba, 2019.

Fonte: Acervo do autor.

E: Considerando os diferentes contextos e movimentações em cada local escolhido, assim como uma certa imprevisibilidade inerente à proposta, poderia mencionar os acontecimentos mais marcantes do projeto até agora?

FMC: Esse é aquele tipo de pergunta que derruba... Porque é tanta coisa que fica difícil incluir algumas e não citar outras. Então, pra responder esse tipo de pergunta de "melhores ou as três mais" não pode pensar muito, vou falar o que vier à cabeça primeiro. Essas surpresas que narrei, das pessoas se deitarem comigo, foi 
impressionante. Ouvir as pessoas lendo também... Ou a menininha que veio me perguntar se eu tinha morrido. Eu nem precisei responder, bastou olhar pra ela pra ela perceber que eu "tô vivão, eis-me aqui". Isso tudo na primeira ação, e ao longo dos trabalhos a gente vai somando várias histórias. Por exemplo, num evento que a gente fez na Casa das Rosas, com um poema do Haroldo de Campos, escrevemos com guardanapos e colocamos paçocas por cima, embaladinhas, pra quem quisesse pegar mesmo. Aí umas crianças apareceram e uma mãe gritou desesperada "meu filho, não toca em nada pelo amor de Deus". Foi o modo dela dizer "don't touch, it's art", sabe? É esse o modo dominante. E eu querendo poder dizer "toque, é arte", e é pra isso mesmo, pra tocar e ser tocada. Mas eu não dizia, porque a ideia é abrir pras interpretações, não dar uma indicação tão explícita de como proceder. Por isso, pra gente é fundamental estar na rua, e não nos espaços institucionalmente destinados à arte, que empobrecem nossa proposta de abertura à alteridade. A gente tinha pensado justamente nas pessoas pegarem as paçocas e a escrita ir se desfazendo, de modo antropofágico mesmo, por isso também as paçocas na embalagem, com guardanapos embaixo, pra ninguém pensar que tivesse sujo e não fosse pra comer. Pelo contrário! Isso de crianças tentarem pegar aconteceu mais de uma vez nesse dia. Só as crianças sacaram! Uma delas tentou retrucar, "mas mãe, no meio a fome". Ela leu o texto, viu a paçoca e entendeu tudo! Mas a cultura, essa aura da arte, impossibilitou o entendimento da mãe. O legal foi que no final, depois que eu levantei e fiquei na câmera, uns garotos que ficam no farol entraram na Casa e mandaram ver, encheram a caixinha deles com paçoca. Quando nos viram filmando lá em cima, se esconderam no arbusto e fugiram, mesmo a gente dizendo pra eles pegarem, que era essa mesmo a ideia. Não teve jeito, eles sumiram. Desarmamos a câmera e quando íamos saindo passamos pelos meninos, que tavam ali de novo, tinham voltado pra terminar de encher as caixinhas deles de paçoca. Eles olharam desconfiados e dessa vez conseguimos falar que era pra eles pegarem tudo mesmo. 
Quer dizer, é esse tipo de transformação em que acredito! Não me parece tão utópico. E só pra citar uma terceira, pra fechar com três que é um número bonito, teve Recife... O que foi aquilo? Apesar de avós paraibanos, eu nunca tinha ido ao Nordeste. E lá a gente conseguiu se articular com uma ocupação liderada por mulheres num local significativo da cidade, a Praça da Independência, no centro. A participação das crianças de lá também foi demais! Aliás, as crianças são as que mais participam dos trabalhos, atrás apenas da polícia, que é o público mais fiel que temos: deu as caras em São Paulo, Rio, Curitiba e Florianópolis. A polícia sempre prestigia nosso trabalho, participa espontaneamente, sem ser chamada... Em Curitiba, inclusive, ficaram tão interessados que fizeram perguntas sobre o que estávamos fazendo! Ah, Curitiba... Bom, voltando às coisas boas, pra mim o que importa é se eu consegui, mesmo que modestamente, dar alguma perspectiva pra essas crianças. Sabe, o fato de eu ter trilhado esse caminho é uma contingência. Eu não tenho sobrenome, na minha casa não tinha biblioteca, em criança nunca me levaram a museus, nunca me disseram que havia canção brasileira pra além do que tocava na TV... Mas sabe, não tô dizendo isso pra demonizar ninguém, pelo contrário, é que é estrutural, também não houve ninguém pra falar pra eles. Mas enfim, em algum momento eu acabei descobrindo que há outros modos de vida, e se esse contato com nossa ação puder ter aberto, ao menos um pouquinho, os caminhos possíveis praqueles garotos que vendiam doce no farol ou que moravam na ocupação tudo já terá valido a pena. Acho que a poesia é isso, não é o que tá pronto, mas a própria transformação. É difícil, claro, é uma coisa pequena e modesta, mas quero crer que algo ficou pra eles e que, eles sim, possam fazer algo maior. 


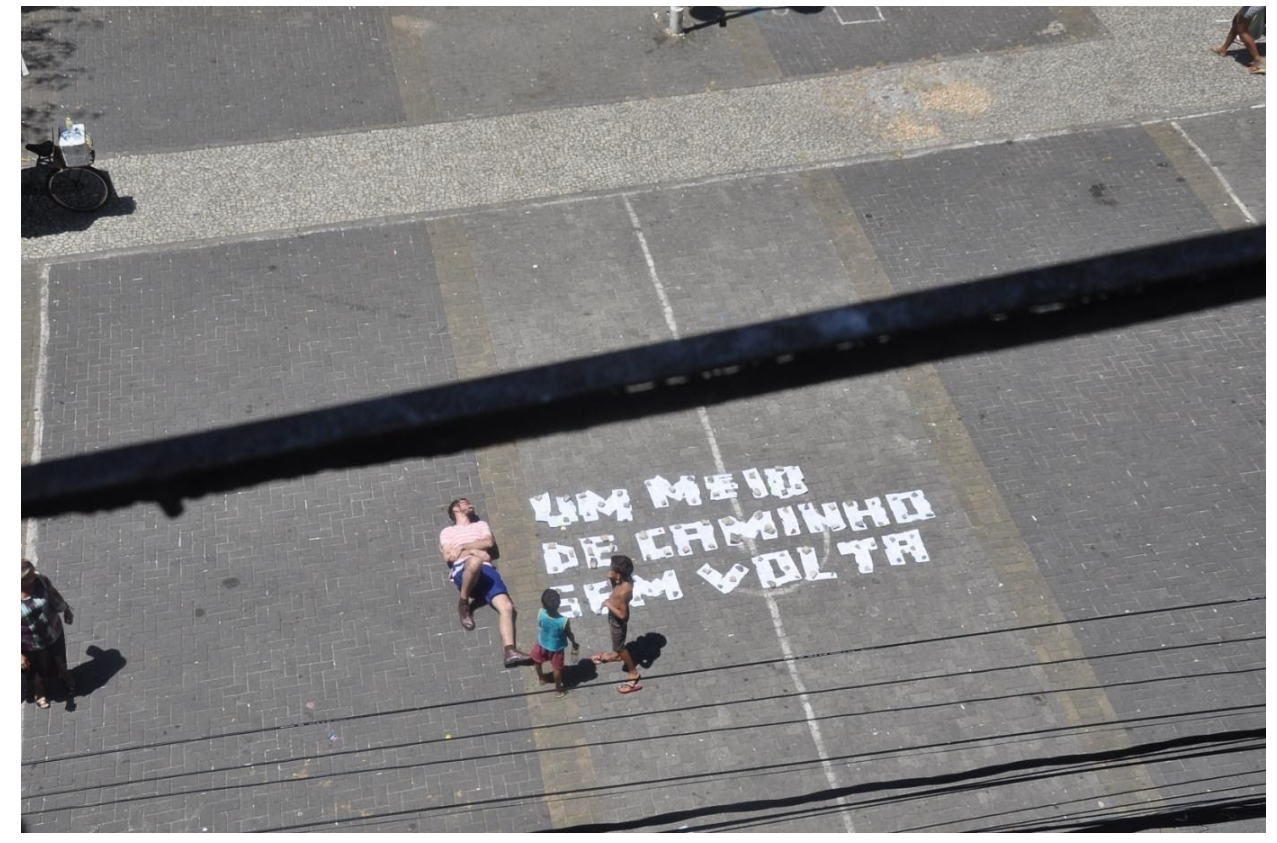

Figura 11: Escritas do efêmero \#5: volta, Recife, 2018.

Fonte: Acervo do autor.

E: É pouco e é tanto, realmente... O que você gostaria que ficasse pra todos nós, incluindo você mesmo?

FMC: Ah, acho que o que eu quero pra mim é o que eu quero que todos possam ter. Que a gente saiba dar atenção ao céu e ao chão, que saiba andar, sentar e deitar e agir quando tudo cair por terra. Afinal, a terra sempre estará aí. Primeiro, por baixo de nós; depois, por cima. 


\title{
Resumo
}

Felipe Marcondes da Costa, um dos idealizadores de Escritas do efêmero, nasceu em 1990 em São Paulo. Tem formação em dramaturgia pela SP Escola de Teatro e Letras pela FFLCH-USP, instituição em que faz mestrado em Literatura Portuguesa pesquisando a relação entre poesia e a arte da performance na obra de Herberto Helder. Seu interesse nessa zona fronteiriça se desdobra em práticas que, como portais, separam e unem expressões artísticas e suscitam a discussão sobre o que é considerado ou não arte. No projeto poemasemdinheiro escreve versos em cédulas, em desencapados os poemas vão parar em documentos oficiais e em Escritas do efêmero os versos estampam as ruas de diversas cidades para serem apagados pelo tempo e deixarem todo o resto que não se apaga. Este diálogo foi realizado presencialmente em agosto de 2019 e sua transcrição foi posteriormente revisada pelo autor.

Palavras-chave: Performance. Arte contemporânea. Escrita performativa.

\begin{abstract}
Felipe Marcondes da Costa, one of the creators of Escritas do efêmero, was born in 1990 in São Paulo. He has a degree in dramaturgy from SP Escola de Teatro and Portuguese Languages and Literatures from Faculdade de Filosofia, Letras e Ciências Humanas da Universidade de São Paulo, an institution where holds a master degree in Portuguese Literature researching the relationship between poetry and the art of performance in Herberto Helder's work. His interest in this border area unfolds in practices that, as portals, separate and unite artistic expressions and arouse discussion about what is considered or not art. In the project poemasemdinheiro writes verses in banknotes, in desencapados the poems end up in official documents and in Escritas do efêmero the verses print the streets of various cities. This dialogue was held in person in August 2019 and its transcript was later revised by the author.
\end{abstract}

Keywords: Performance art. Contemporary art. Performative writing. 
DOI:10.20396/urbana.v11i3.8656275

\section{Resumen}

Felipe Marcondes da Costa, uno de los creadores del Escritas do Efêmero, nació en 1990 en São Paulo. Se formó en dramaturgia por la SP Escola de Teatro y es licenciado en Letras por la Faculdade de Filosofia, Letras e Ciências Humanas da Universidade de São Paulo, institución en la cual hace maestría en Literatura Portuguesa investigando la relación entre poesía y la arte del performance en la obra de Herberto Helder. Su interés en esta área fronteriza se despliega en prácticas que, como portales, separan y unen expresiones artísticas y promueven la discusión acerca de lo que se considera o no arte. En el proyecto poemasemdinheiro escribe versos en billetes, en desencapados los poemas son inseridos en documentos oficiales; ya en Escritas do efêmero se inscriben los versos en las calles de múltiples. Eso dialogo fue realizado presencialmente en agosto de 2019 y su transcripción fue revisada posteriormente por el autor.

Palabras clave: Performance. Arte contemporáneo. Escritura performativa. 